\title{
Optimalisasi Peran Penegak Hukum Dalam Menerapkan Pidana Kerja Sosial Dan Ganti Rugi Guna Mewujudkan Tujuan Pemidanaan Yang Berkeadilan
}

\author{
Sahat Maruli Tua Situmeang, Musa Darwin Pane, dan Wahyudi \\ Fakultas Hukum Universitas Komputer Indonesia, Bandung, Jawa Barat, Indonesia \\ Jln. Dipati Ukur No. 116 -112, Bandung, Jawa Barat, Indonesia \\ sahat@email.unikom.ac.id, musa@email.unikom.ac.id, \\ wahyudiyurispruden@gmail.com
}

Received: 1 Mei 2020; Accepted: 20 Oktober 2020; Published: 15 Desember 2020 https://doi.org/10.20885/iustum.vol27.iss3.art4

\begin{abstract}
This study aims to determine the obstacles in implementing social work sanction and compensation by law enforcers and the efforts that must be undertaken in order to achieve the objective of fair punishment. The approach method in this research is a sociological juridical approach. The research specifically used analytical descriptive method. The results of this study conclude that social work criminal sanction have not been implemented by law enforcers, this is because there is no clear regulation in the form of legislation as the legal basis, including the absence of an institution that functions to oversee the implementation of social work sanction and compensation. As for the efforts aside of the support for the establishment of laws and regulations so that social work sanction can be applied, is also by the courage of law enforcers to implement social work sanction, so that the objectives of fair punishment can be realized.
\end{abstract}

Key Words: Criminal objectives; law enforcement; social work sanction

\section{Abstrak}

Penelitian ini bertujuan untuk mengetahui hambatan dalam menerapkan pidana kerja sosial dan ganti rugi oleh penegak hukum serta upaya-upaya yang harus dilakukan guna mewujudkan tujuan pemidanaan yang berkeadilan. Metode pendekatan dalam penelitian ini adalah pendekatan yuridis sosiologis. Spesifikasi penelitian menggunakan metode deskriptif analitis. Hasil dari studi ini menyimpulkan bahwa sanksi pidana kerja sosial belum dapat diterapkan oleh penegak hukum, hal tersebut dikarenakan belum adanya regulasi yang jelas dalam bentuk peraturan perundang-undangan sebagai landasan hukumnya termasuk belum terbentuknya lembaga yang berfungsi melakukan pengawasan terhadap pelaksanaan pidana kerja sosial dan ganti rugi. Adapun upaya selain dukungan adanya peraturan perundang-undangan agar pidana kerja sosial dapat diterapkan yaitu dengan adanya keberanian dari penegak hukum untuk menerapkan pidana kerja sosial, sehingga tujuan pemidanaan yang berkeadilan dapat terwujud.

Kata-kata Kunci : Penegakan hukum; pidana kerja sosial; tujuan pemidanaan 


\section{Pendahuluan}

Pasal 1 ayat (3) Undang-Undang Dasar Negara Republik Indonesia Tahun 1945 (UUD NRI 1945) mengamanatkan bahwa negara Indonesia sebagai negara hukum. Menurut Kaelan, ciri dari negara hukum yaitu adanya pengakuan dan perlindungan hak-hak asasi, peradilan yang bebas dan bersih dari pengaruh lain, serta adanya kepastian hukum. ${ }^{1}$ Oleh karenanya, segala persoalan warga negara dan pemerintahannya harus didasarkan pada hukum yang berlaku agar terciptanya ketertiban dalam masyarakat.

Over kapasitas dalam lembaga pemasyarakatan merupakan konsekuensi logis yang tak terbantahkan dari penerapan sanksi pidana pidana penjara yang selalu diterapkan atau dijatuhkan oleh Hakim yang apabila ditinjau dari sudut tujuan pemidanaan dianggap masih belum efektif. Saat penelitian ini dilakukan, jumlah lapas seluruhnya mencapai 528 dengan kapasitas 130.512 orang, sementara jumlah penghuni lapas dan rutan sebanyak 269.846 orang, sehingga terdapat over kapasitas sebanyak $107 \%{ }^{2}$ Sementara itu, berdasarkan data dari http://smslap.ditjenpas.go.id/, dalam kurun waktu 3 tahun terakhir dalam rentang waktu 2017 sampai 2019 menunjukan adanya over kapasitas yang terus meningkat. Pada 2017 jumlah narapidana sebanyak 232.081 dengan kapasitas Lapas sebanyak 133.169 narapidana, sehingga terjadi over kapasitas sebanyak 74 \%. Pada 2018 jumlah narapidana sebanyak 255.380 dengan kapasitas Lapas sebanyak 133.169 narapidana, sehingga terjadi over kapasitas sebanyak $92 \%$. Sementara pada 2019 jumlah narapidana sebanyak 265.648 dengan kapasitas Lapas sebanyak 133.169 narapidana, sehingga terjadi over kapasitas sebanyak 99 $\%$. Berdasarkan hal tersebut, dapat terlihat bahwa penerapan pidana sanksi sosial dan pembayaran ganti rugi belum turut berperan dan belum terlihat diterapkan dalam sistem pemidanaan dalam upaya menanggulangi tindak pidana.

Kejahatan merupakan gejala sosial yang telah ada sejak dahulu kala. Menurut Muhammad Mustafa, secara kriminologi, kejahatan merupakan suatu pola tingkah

1 Sahat Maruli Tua Situmaeng, "Kebijakan Kriminal Dalam Penegakan Hukum Untuk Mewujudkan Keadilan Dalam Perspektif Hak Asasi Manusia”, Res Nullius Law Journal1 (1), 2019, diakses dari https://doi.org/10.34010/rnlj.v1i1.2492., hlm. 27.

2 Yeremia Sukoyo., “Over kapasitas Lapas capai 107 persen”. https://www.beritasatu.com/jajasuteja/nasional/592646/over-kapasitas-lapas-capai-107persen\#: :text=Jumlah $\% 20$ lapas $\% 20$ dan $\% 20$ rutan $\% 20$ di,terdapat $\% 20$ overcrowded $\% 20$ sebanyak $\% 20107 \% 20$ pe rsen., diakses pada tanggal 2 September 2020 
laku yang merugikan masyarakat dan suatu pola tingkah laku yang mendapatkan reaksi sosial dari masyarakat. ${ }^{3}$ Dalam mengendalikan kejahatan supaya berada pada "batas-batas toleransi" masyarakat, namun tidak berarti memberikan toleransi terhadap suatu kejahatan untuk terjadi, maka diperlukan suatu pengendalian sosial dengan menerapkan sanksi pidana kerja sosial dan ganti rugi sebagai alternatif pemidanaan. Pengendalian sosial merupakan suatu sistem untuk mencegah terjadinya penyimpangan sosial di dalam masyarakat, di mana dalam prosesnya, diperlukan keterlibatan dari berbagai unsur atau pihak baik dari unsur pemerintah maupun dari unsur masyarakat melalui upaya-upaya pengawasan dengan tujuan agar sesuai dengan nilai-nilai yang hidup dalam masyarakat. ${ }^{4}$

Sanksi pidana penjara masih menjadi primadona dalam penegakan hukum pidana. Namun demikian, secara statistik kejahatan terus meningkat, baik dilihat dari segi kuantitas maupun dari segi kualitasnya. Dengan demikian, seyogyanya pemerintah sudah memikirkan untuk dapat menerapkan sanksi pidana kerja sosial dan ganti rugi sebagai alternatif pemidanaan melalui suatu regulasi atau peraturan perundang-undangan sebagai suatu upaya untuk melakukan pencegahan dan penanggulangan kejahatan dengan melakukan reformulasi terhadap sistem pemidanaan serta optimalisasi peran penegak hukum dalam menerapkan pidana kerja sosial dan ganti rugi guna mewujudkan tujuan pemidanaan yang berkeadilan, sebagaimana yang dimaksud dalam penologi. Penologi adalah suatu studi mengenai reformasi dan rehabilitasi narapidana dan pengelolaan penjara. ${ }^{5}$

Berkaitan dengan hal tersebut, pemidanaan dalam Rancangan UndangUndang Kitab Undang-Undang Hukum Pidana (RUU KUHP) khususnya yang harus lebih dipahami secara seksama oleh para hakim dan aparat penegak hukum lainnya dituntut untuk lebih membuka pemikiran tentang beragam tujuan dan fungsi pemidanaan dan tidak berkutat di lingkup retributif belaka. Adanya perubahan pola pikir dari para penegak hukum juga sangat diharapkan dapat

\footnotetext{
${ }^{3}$ Nafi Mubarok, "Pidana Qisas dalam Perspektif Penologi”, Jurnal Al-Qanun, Vol. 20 No. 2 Desember 2017, hlm. 224.

${ }^{4}$ Mas Ahmad Yani, "Pengendalian Sosial Kejahatan : Suatu Tinjauan Terhadap Masalah Penghukuman Dalam Perspektif Sosiologi”, Jurnal Cita Hukum, Vol. 3 No. 1 Juni 2015, hlm. 78.

${ }^{5}$ C. Djisman Samosir, Penologi dan Pemasyarakatan, Cetakan Pertama, Nuansa Aulia, Bandung, 2016, hlm. 2.
} 
memberikan dampak dalam penanganan perkara pidana di lapangan. ${ }^{6}$ Secara prinsip baik dalam mekanisme maupun doktrin hukum, bahwa sistem peradilan pidana terpadu (SPPT) dan kedudukan pemasyarakatan kerap dikaitkan dengan tahapan akhir dari sebuah perjalanan sistem hukum pidana Indonesia yang dalam prosesnya telah dikenal dengan adanya beberapa sub-sistem, mulai dari institusi Kepolisian sebagai pemangku kekuasaan dalam proses pelaksanaan penyelidikan, penyidikan dan penetapan tersangka, Kejaksaan yang memiliki kewenangan menuntut sebagai representatif negara, Pengadilan yang memiliki kekuasaan dalam memeriksa perkara dan pemasyarakatan dengan kekuasaan penghukuman. ${ }^{7}$

Secara filosofis, pemasyarakatan adalah sistem pemidanaan yang sudah jauh bergerak meninggalkan filosofi retributif (pembalasan), detterence (penjeraan) dan resosialisasi. Dengan kata lain, pemidanaan tidak ditujukan untuk membuat derita sebagai bentuk pembalasan, tidak ditujukan untuk membuat jera dengan penderitaan, juga tidak mengasumsikan terpidana sebagai seseorang yang kurang sosialisasinya. Pemasyarakatan sejalan dengan filosofi reintegrasi sosial yang berasumsi kejahatan adalah konflik yang terjadi antara terpidana dengan masyarakat. Sehingga pemidanaan ditujukan untuk memulihkan konflik atau menyatukan kembali terpidana dengan masyarakatnya (reintegrasi). ${ }^{8}$ Akan tetapi, adanya over kapasitas menunjukkan bahwa kurang efektifnya pidana penjara dalam penanggulangan kejahatan, namun eksistensi sistem penjara masih terlihat meskipun berdasarkan Undang-Undang Nomor 12 Tahun 1995 telah diganti dengan sistem pemasyarakatan. Lapas sebagai pelaksana pembinaan narapidana dan merupakan bagian dari sub sistem peradilan pidana sebagaimana diamanatkan dalam Undang-Undang No. 12 Tahun 1995 tentang Pemasyarakatan, meski demikian bahwa tujuan pembinaan napi ini menghadapi hambatan dan implikasi pada kurang optimalnya bahkan dapat menuju kegagalan fungsi sebagai lembaga pembinaan, seperti misalnya terjadinya kelebihan hunian (overcapacity), hal ini bukan

${ }^{6}$ Harkristuti Harkrisnowo, "Redefinisi Pidana dan Pemidanaan Korporasi Dalam Perspektif Rancangan Undang-Undang Kitab Undang-Undang Hukum Pidana”, Jurnal Legislasi Indonesia, Vol. 16 No. 4 Desember 2019, hlm. 415.

7 Fachrurrozy Akmal, "Penologi Pengayoman, Sebuah Tinjauan Pemidanaan Dalam Integrasi Ilmu Pengetahuan”, Jurnal Khatulistiwa Law Review, Vol. 1 No. 1, April 2020, hlm. 40.

${ }^{8}$ Iqrak Sulhin, "Filsafat (Sistem) Pemasyarakatan", Jurnal Kriminologi Indonesia, Vol. 7 No. 1 Mei 2010, hlm. 139. 
merupakan faktor kondusif bagi suatu proses pembinaan narapidana yang tujuan pemidanaannya antara lain reintegrasi sosial dan dapat kembali diterima oleh masyarakat serta dapat menjalankan perannya sebagai anggota masyarakat. ${ }^{9}$

Dalam praktiknya, terpidana yang berada di lembaga pemasyarakatan kurang terbina dengan baik, yang dipengaruhi oleh beberapa faktor, diantaranya kualitas dan kuantitas petugas lapas, sarana dan prasarana yang kurang memadai, program pembinaan yang tidak berjalan dan lain sebagainya. Runtutan peristiwa tersebut berakibat pada kualitas sanksi pidana penjara serta seberapa besar integritas dan profesionalisme penegak hukum dalam menegakkan hukum. Penjatuhan pidana penjara memberikan dampak negatif yakni adanya stigmatisasi yang berdampak panjang pada narapidana yang menjalani pidana penjara jangka pendek baik terhadap diri pelaku maupun masa depannya, berpotensinya penyimpangan-penyimpangan seksual akibat terampasnya kehidupan seksual yang normal dari seseorang, hilangnya mata pencaharian bagi ekonomi keluarga yang ditinggalkan serta berdampak pula terhadap keharmonisan keluarga pada pelaku kejahatan yang merupakan tulang punggung keluarga. ${ }^{10}$

Saat ini, sanksi pidana kerja sosial masih merupakan konsep dalam RUU KUHP yang saat ini belum dapat diterapkan. Oleh karenanya, para penegak hukum belum menerapkan pidana kerja sosial dalam penerapan sanksi pidana karena regulasinya belum ada. Di dalam RUU KUHP sanksi pidana kerja sosial tercantum di dalam Pasal 65 yang menyebutkan bahwa pidana pokok terdiri atas pidana penjara, pidana tutupan, pidana pengawasan, pidana denda dan pidana kerja sosial. Di dalam penjelasannya disebutkan bahwa pidana tutupan, pidana pengawasan dan pidana kerja sosial pada dasarnya merupakan suatu model pelaksanaan pidana sebagai alternatif dari pidana penjara. Pencantuman jenis pidana ini merupakan konsekuensi diterimanya hukum pidana yang bersifat daad-daderstrafrecht yang sejauh mungkin berusaha untuk mengembangkan alternatif pidana kemerdekaan, karena ketentuan dalam undang-undang ini

9 Angkasa, "Over Capacity Narapidana Di Lembaga Pemasyarakatan, Faktor Penyebab, Implikasi Negatif, Serta Solusi Dalam Upaya Optimalisasi Pembinaan Narapidana”, Jurnal Dinamika Hukum, Vol. 10 No. 3 September 2010, hlm. 214.

${ }^{10}$ Yolanda, Lise. Eksistensi Pidana Kerja Sosial Sebagai Sanksi Pidana Dalam Rancangan Undang-Undang Kuhp Indonesia. Diss. Universitas Islam Indonesia, 2016., hlm. 5. 
bukan hanya berorientasi pada perbuatan tetapi juga berorientasi pada pelaku. Beranjak dari berbagai permasalahan di atas, tentunya penelitian ini menjadi sangat urgen guna memberikan masukan atas riset ilmu hukum khususnya mengenai diskursus penerapan sanksi pidana kerja sosial dan ganti rugi secara optimal oleh penegak hukum yang masih cukup terbatas.

\section{Rumusan Masalah}

Berdasarkan dari penjelasan latar belakang di atas, maka yang menjadi permasalahan untuk diteliti yaitu, sebagai berikut. Pertama, mengapa penegak hukum belum menerapkan sanksi pidana kerja sosial dan ganti rugi secara optimal? Kedua, upaya apa yang seharusnya dilakukan agar penegak hukum dapat mengoptimalkan penerapan sanksi pidana kerja sosial dan ganti rugi sehingga tercapainya tujuan pemidanaan yang berkeadilan?

\section{Tujuan Penelitian}

Berdasarkan uraian dalam latar belakang yang telah dirumuskan, maka secara keseluruhan tujuan dari penelitian ini, sebagai berikut. Pertama, untuk mengetahui hambatan penegak hukum dalam penerapan sanksi pidana sosial dan ganti rugi. Kedua, untuk mengetahui upaya yang harus dilakukan oleh penegak hukum dalam menerapkan pidana kerja sosial dan ganti rugi guna mewujudkan tujuan pemidanaan yang berkeadilan.

\section{Metode Penelitian}

Metode pendekatan yang digunakan dalam penelitian ini adalah pendekatan yuridis sosiologis yaitu menggambarkan secara rinci fenomena sosial yang menjadi pokok permasalahan tanpa melakukan suatu hipotesa dan perhitungan secara statistik. Pendekatan yuridis sosiologis dimaksudkan sebagai pemaparan dan pengakajian hubungan aspek hukum di dalam kenyataan. Spesifikasi penelitian menggunakan metode deskriptif analitis, yakni suatu penelitian yang menggambarkan, menemukan fakta-fakta hukum secara menyeluruh dan mengkaji secara sistematis terhadap data sekunder. 


\section{Hasil Penelitian dan Pembahasan}

\section{Sanksi Pidana Kerja Sosial Dan Ganti Rugi Belum Diterapkan Secara Optimal}

Dalam suatu negara, terdapat sistem hukum yang di dalamnya memiliki komponen. Menurut Lawrence M. Friedman, sistem hukum harus memiliki 3 komponen yaitu struktur (structure), substansi (subtance), dan kultur hukum (legal culture). Pertama, sistem hukum mempunyai struktur, dalam hal ini sistem hukum terus berubah, namun bagian-bagian sistem itu berubah dalam kecepatan yang berbeda dan setiap bagian berubah tidak secepat bagian tertentu lainnya. Ada pola panjang yang berkesinambungan. Struktur sistem hukum, dengan kata lain adalah kerangka atau rangkaian, bagian yang tetap bertahan, bagian yang memberi semacam bentuk dan batasan terhadap keseluruhan. Kedua, sistem hukum mempunyai substansi, yang dimaksud dengan substansi adalah aturan, norma dan pola perilaku manusia yang nyata dalam sistem hukum. Ketiga, sistem hukum mempunyai kultur (budaya hukum) adalah sikap manusia terhadap hukum dan sistem hukum di dalamnya terdapat kepercayaan, nilai, pemikiran serta harapannya. ${ }^{11}$

Selain itu apabila merujuk pada pengertian atau definisi dari hukum pidana yaitu aturan hukum dari suatu negara yang berdaulat yang berisi perbuatan yang dilarang atau diperintahkan disertai dengan ancaman pidana bagi siapa yang melanggar atau tidak mematuhi kemudian kapan dan dalam hal apa pidana itu dapat dijatuhkan serta bagaimana pelaksanaan pidana tersebut yang keberlakuannya dipaksakan oleh negara. Dari pengertian tersebut terdapat 3 hal penting dalam hukum pidana yaitu perbuatan pidana, pertanggungjawaban pidana dan sanksi pidana. Berdasarkan hal tersebut, maka secara substansi nilainilai pokok hukum pidana bertujuan untuk tercapainya keamanan dan ketertiban. Dalam konsep pemidanaan maka pidana kerja sosial sejalan dengan konsep pidana sebagai ultimum remedium. Selain itu dimungkinkannya adanya diskresi pejabat yang tetap memerlukan suatu aturan tertulis sehingga pidana kerja sosial dapat diterapkan dalam penjatuhan pidana.

11 Anwar, Yesmil. "Adang, Sistem Peradilan Pidana: Konsep, Komponen, dan Pelaksanaannya dalam Penegakan Hukum di Indonesia." (2009). hlm. 31. 
Peran dalam ilmu sosial berarti suatu fungsi yang dibawakan seseorang ketika menduduki jabatan tertentu, seseorang dapat memainkan fungsinya karena posisi yang didudukinya tersebut. Sedangkan peranan menurut Soerjono Soekanto merupakan aspek dinamis kedudukan (status) apabila seseorang melaksanakan hak dan kewajibannya maka ia menjalankan suatu peranan. ${ }^{12}$ Setiap penegak hukum mempunyai kedudukan (status) dan peranan (role). Kedudukan merupakan posisi tertentu di dalam struktur kemasyarakatan. Kedudukan tersebut sebenarnya merupakan suatu wadah yang isinya hak-hak dan kewajiban-kewajiban tertentu. ${ }^{13}$

Berkaitan dengan hal tersebut, kurangnya profesionalitas dan integritas para penegak hukum yang menyebabkan tujuan pemidanaan tidak tercapai. Oleh karenanya, tidak saja peraturannya yang baik akan tetapi integritas para penegak hukum sebagai corong keadilan merupakan hal yang sama pentingya. Berdasarkan hal tersebut, peranan para penegak hukum turut menentukan keberhasilan sistem pembinaan di lembaga pemasyarakatan, yang didalamnya adanya proses interaksi dalam menjalankan program-program pembinaan, yang senyatanya belum dapat optimal. ${ }^{14}$

Sebagai salah satu komponen sistem peradilan pidana yang secara langsung berhadapan dengan tindak pidana yang terjadi dalam masyarakat yaitu lembaga Kepolisian. ${ }^{15}$ Kepolisian merupakan sub sistem yang memiliki tugas, tanggung jawab dan kewenangan berdasarkan Undang-Undang Nomor 2 Tahun 2002 Tentang Kepolisian Negara Republik Indonesia serta merupakan sub sistem dalam sistem peradilan pidana yang menentukan keberhasilan dan kerja keseluruhan sistem peradilan pidana dalam memberikan pelayanan kepada masyarakat karena secara langsung berhubungan dengan pelaku tindak pidana dan masyarakat. Dalam menjalankan tugas dan kewenangannya, Kepolisian

\footnotetext{
${ }^{12}$ Suwari Akhmaddhian, "Peran Pemerintah Daerah Dalam Mewujudkan Hutan Konservasi Berdasarkan Undang-Undang Nomor 41 Tahun 1999 Tentang Kehutanan”, Jurnal Dinamika Hukum, Vol. 13 No. 3 , September 2013, hlm. 449-450.

13 Guntur Priyantok, "Penerapan Diskresi Kepolisian Dalam Penanganan Unjuk Rasa", De Lega Lata, Vol. 1 No. 1, Januari 2016, hlm. 113

14 Desy Maryani, "Faktor-Faktor Penyebab Tidak Tercapainya Tujuan Pemidanaan Lembaga Pemasyarakatan Di Indonesia”, Jurnal Hukum Schasen, Vol. 1 No. 1 April 2015, hlm. 12.

${ }^{15}$ Edi Setiadi, Sistem peradilan Pidana Terpadu dan Sistem Penegakan Hukum di Indonesia, Cetakan Pertama, Prenada Media Group, Jakarta, 2017, hlm. 113.
} 
memiliki kewenangan untuk menggunakan diskresi atau pertimbangan pemikiran untuk mengambil suatu sikap atau kebijakan atas perkara yang sedang ditanganinya dengan mengacu pada memilih berbagai alternatif penyelesaiannya, seperti misalnya melalui musyawarah mufakat atau restoratif justice.

Adapun yang menjadi landasan diperlukannya diskresi dalam pelaksanaan tugas Polri karena tidak adanya peraturan perundang-undangan yang sedemikian lengkapnya dalam mengatur tingkah laku manusia, adanya keterlambatan dalam menyesuaikan peraturan perundang-undangan dalam perkembangan masyarakat serta kurangnya biaya dalam menerapkan peraturan perundang-undangan.16 Senada dengan hal tersebut, Rufinus Hotmaulana Hutauruk menyatakan bahwa proses penanggulangan tindak pidana melalui pendekatan atau konsep keadilan restoratif adalah suatu proses penyelesaian tindak pidana yang bertujuan untuk memulihkan keadaan yang di dalamnya termasuk ganti rugi terhadap korban melalui cara-cara tertentu yang telah disepakati oleh para pihak yang terlibat. Prinsip utama penyelesaian tindak pidana melalui pendekatan atau konsep keadilan restoratif merupakan suatu penyelesaian yang bukan hanya sekedar alat untuk mendorong seseorang untuk melakukan kompromi demi terciptanya kesepakatan, tetapi pendekatan dimaksud harus mampu menembus ruang hati dan pikiran para pihak yang terlibat dalam proses penyelesaian dalam memahami makna dan tujuan dilakukannya suatu pemulihan dan sanksi yang diterapkan adalah sanksi yang memulihkan dan bersifat mencegah. ${ }^{17}$ Namun biasanya, dengan berdasarkan adanya 2 alat bukti, penyidik tetap merujuk untuk melanjutkan ke tahap pengadilan untuk membuktikan terbukti atau tidak terbukti. Apabila tersangka melakukan permohonan untuk dilakukannya pemeriksaan di praperadilan, maka praperadilan tersebut dijalankan terlebih dahulu. Istilah praperadilan diambil dari kata "pre trial", walaupun fungsi dan tujuan pretrial adalah meneliti apakah ada dasar hukum yang cukup untuk mengajukan penuntutan mengenai suatu perkara pidana yang dituduhkan dihadapan pengadilan yang berbeda dengan maksud bahwa praperadilan yang dimohonkan tersebut bertujuan untuk

\footnotetext{
16 Son Haji, Gunarto, Widayati, "Implementasi Kewenangan Diskresi Kepolisian Dalam Penanganan Tindak Pidana Di Polres Demak Jawa Tengah”, Jurnal Hukum Khaira Ummah, Vol. 13 No. 1, Maret 2018, hlm. 59

${ }^{17}$ Edi Setiadi, Sistem peradilan Pidana Terpadu dan Sistem Penegakan Hukum di Indonesia..., Op. Cit., hlm. 230.
} 
melindungi hak asasi tersangka terhadap pelanggaran penerapan syarat formil maupun syarat materiil yang dijadikan sebagai pertimbangan dalam tingkat penyelidikan, penyidikan, penahanan, penggeledahan, penyitaan, pemeriksaan surat, hak-hak tersangka/terdakwa dan mengenai bantuan hukum. Berdasarkan Pasal 1 butir $10 \mathrm{KUHAP}$, praperadilan hanya akan memeriksa dan memutus tentang sah atau tidaknya suatu penangkapan dan/atau penahanan atas permohonan tersangka dan/atau keluarga atau kuasanya, sah atau tidaknya penghentian penyidikan atau penghentian penuntutan atas permohonan tersangka/penyidik/penuntut umum, permohonan ganti kerugian atau rehabilitasi oleh tersangka atau keluarganya atau kuasanya yang perkaranya tidak diajukan ke pengadilan. Akan tetapi praperadilan ini dianggap belum berjalan sebagaimana yang diharapkan oleh para pemohon karena terdapatnya kelemahan dan kekurangan dalam prakteknya.

Kejaksaan dalam sistem peradilan pidana bekerja setelah adanya pelimpahan perkara dari kepolisian. Kejaksaan merupakan lembaga pemerintahan dibidang penuntutan serta tugas lain yang ditetapkan berdasarkan undang-undang. Sementara Pengadilan merupakan lembaga yang memeriksa dan menuntut suatu perkara dan kewenangannya sebagai salah satu penyelenggara Kekuasaan Kehakiman. Lembaga pemasyarakatan bertugas untuk melakukan pembinaan kepada pelaku tindak pidana, sedangkan Advokat adalah semua orang yang memiliki profesi untuk memberikan jasa hukum, baik didalam maupun diluar pengadilan sesuai dengan ketentuan undang-undang.

Berdasarkan uraian tersebut di atas, bahwasanya sistem peradilan pidana tersebut selalu melibatkan dan mencakup sub-sub sistem dengan ruang lingkup masing-masing proses peradilan pidana. Jika dilihat dari kacamata hukum progresif, maka polisi sebagai sub sistem terdepan dalam menentukan suatu status dinaikan kepada proses selanjutnya atau tidak, sehingga Polisi harus menjadi pengayom dan pelindung rakyat yang sesungguhnya bukan hanya sebagai alat Pemerintah untuk menegakan hukum. ${ }^{18}$ Sejalan dengan hal tersebut, Satjipto Raharjo mengatakan bahwa penegakan hukum progresif adalah

18 Mahrus Ali, "Sistem Peradilan Pidana Progresif; Alternatif Dalam Penegakan Hukum Pidana”, Jurnal Hukum, Vol. 2 No. 14, April 2017, hlm. 219-220. 
menjalankan hukum tidak hanya sekedar kata-kata hitam-putih dari peraturan (according to the letter), melainkan menurut semangat dan makna lebih dalam (to very meaning) dari undang-undang atau hukum. Penegakan hukum tidak hanya kecerdasan intelektual, melainkan dengan kecerdasan spriritual. Dengan kata lain, penegakan hukum yang dilakukan dengan penuh determinasi, empati, dedikasi, komitmen terhadap penderitaan bangsa dan disertai keberanian untuk mencari jalan lain daripada yang biasa dilakukan. ${ }^{19}$

Sementara teori hukum integratif memiliki peranan penting dan menentukan dalam mendefinisikan dan mempertahankan nilai-nilai dan idealisme yang dapat memelihara kesinambungan pandangan hidup kita bersama yaitu Pancasila.20 Menurut hukum integratif, rekayasa hukum, masyarakat dan penegak hukum yang dilakukan haruslah dilandaskan pada sistem norma, sistem perilaku dan sistem nilai yang tidak lain bersumber pada Pancasila sebagai ideologi bangsa Indonesia. ${ }^{21}$

Berdasarkan hal tersebut, seharusnya Penyidik dapat menyaring apakah perkara tersebut merupakan perkara pidana ataukah perkara perdata dan jika terbukti merupakan perkara pidana apakah harus masuk ke ranah pengadilan atau dapat diselesaikan dengan restorative justice. Mengingat bahwa, dalam praktinya terjadi perkara yang diputus di Pengadilan dengan putusan bahwa bukanlah merupakan perkara pidana melainkan perkara perdata, yang mana terdakwa telah menjalani proses penahanan. Kaitannya dengan perkara tersebut, bagaimana pertanggungjawaban aparat penegak hukum ketika hak asasi manusia seseorang dalam hal ini yang diduga melakukan perbuatan pidana telah menjalani penahanan, sementara perlindungan terhadap korban tindak pidana adalah merupakan bagian dari perlindungan hukum bagi warga negara Indonesia. Hak untuk mendapatkan keadilan bagi pelaku kejahatan merupakan hak asasi yang sangat mendasar dimana setiap orang berhak atas pengakuan, jaminan, perlindungan dan perlakuan hukum

\footnotetext{
19 Mukhidin, "Hukum Progresif Sebagai Solusi Hukum Yang Mensejahterakan Rakyat", Jurnal Pembaharuan Hukum, Vol. 1 No. 3 September 2014, hlm. 269.

${ }^{20}$ Romli Atmasasmita, "Memahami Teori Hukum Integratif”, Jurnal Legalita, Vol. III No. 2, Desember 2012, hlm. 13.

21 Romli Atmasasmita, Teori Hukum Integratif Rekonstruksi Terhadap Teori Hukum, http:/ / news.unair.ac.id/2019/06/12/teori-hukum-integratif-sebagai-kontribusi-pemikiran-evolusioner-diindonesia/, Diakses pada tanggal 25 Juni 2020.
} 
yang adil serta mendapat kepastian hukum dan perlakuan yang sama di depan hukum. Setiap orang diakui sebagai manusia pribadi yang berhak menuntut dan memperoleh perlakuan serta perlindungan yang sama sesuai dengan martabat kemanusiannya di depan hukum. Dalam merumuskan prinsip-prinsip perlindungan hukum bagi rakyat (di Indonesia) landasan pijak kita adalah Pancasila sebagai dasar ideologi dan dasar falsafah negara. ${ }^{22}$

Di dalam Pasal 191 ayat (2) KUHAP disebutkan bahwa jika pengadilan berpendapat bahwa perbuatan yang didakwakan kepada terdakwa terbukti, tetapi perbuatan itu tidak merupakan suatu tindak pidana, maka terdakwa diputus lepas dari segala tuntutan hukum. KUHAP telah memberikan macammacam jenis alat bukti yang dapat digunakan dalam sidang pengadilan. Bahwa alat bukti yang sah meliputi keterangan saksi, keterangan ahli, surat, petunjuk, keterangan terdakwa sebagaimana ditentukan dalam Pasal 184 ayat (1) KUHAP. Oleh karena itu, hakim harus berhati-hati, cermat dan matang untuk menilai dan mempertimbangkan nilai dari suatu pembuktian dan wajib untuk mengkaji sejauhmana batas-batas "kekuatan pembuktian" atau bewijskracht dari setiap alat bukti yang disebut dalam Pasal 184 KUHAP. ${ }^{23}$ Sehingga di dalam proses penyidikan tidak cukup hanya dengan 2 alat bukti saja, karena dengan hanya 2 alat bukti saja cenderung masih bersifat subjektif sehingga perlu ditambahkan satu alat bukti lainnya, misalnya keterangan ahli yang menerangkan apakah unsur-unsur pidana yang diterapkan telah terpenuhi atau belum terpenuhi.

Berdasarkan uraian tersebut diatas, terdapat hambatan sehingga sanksi pidana kerja sosial ini belum dapat diterapkan oleh penegak hukum yaitu belum adanya regulasi dalam peraturan perundang-undangan yang mengatur sanksi pidana kerja sosial meskipun terdapat kewenangan diskresi penegak hukum, sistem pengawasan dan pembinaan, belum jelasnya lembaga yang mengawasi pidana kerja sosial, kurangnya tenaga pembimbing kemasyarakatan, sistem pemidanaan pidana penjara masih menjadi primadona dan kepercayaan masyarakat bahwa lembaga pemasyarakatan sebagai lembaga yang memberikan efek jera.

${ }^{22}$ Meldy Ance Almendo, "Prinsip Keadilan Dalam Tanggungjawab Negara Terhadap Korban Tindak Pidana Karena Pelaku Tidak Menjalani Pemidanaan”, Jurnal Yuridika, Vol. 31 No. 1, Januari 2016, hlm. 61.

${ }^{23}$ Bastianto Nugroho, "Peranan Alat Bukti Dalam Perkara Pidana Dalam Putusan Hakim Menurut KUHAP", Jurnal Yuridika, Vol. 32 No. 1, Januari 2017, hlm. 19. 
Seiring dengan perkembangan masyarakat yang sadar akan hukum, aparat penegak hukum dituntut untuk senantiasa melindungi kepentingan umum melalui perbaikan pada materi atau peraturan hukum dan peningkatan kinerja aparat penegak hukum yang diwujudkan melalui pola tingkah laku, profesionalisme dan integritas yang tinggi. Oleh karenanya, diperlukan peningkatan baik secara teknis maupun akademis yang merupakan konsekuensi logis dari perkembangan ilmu pengetahuan dan teknologi tanpa harus meninggalkan sosial budaya bangsanya.

\section{Upaya yang Seharusnya Dilakukan agar Penegak Hukum dapat Mengoptimalkan Penerapan Sanksi Pidana Kerja Sosial dan Ganti Rugi agar Dicapai Keadilan}

Pasal 1 ayat (3) Undang-Undang Dasar 1945 mengamanatkan bahwa negara Indonesia sebagai negara hukum. Artinya, segala persoalan warga negara dan pemerintahannya harus didasarkan pada hukum yang berlaku. Berdasarkan hal tersebut, demi terciptanya ketertiban dalam masyarakat, selain sebagai kontrol sosial, hukum juga berfungsi sebagai alat untuk menyelesaikan konflik atau sengketa yang terjadi dalam masyarakat. Salah satu upaya yang dilakukan dalam menanggulangi kejahatan tersebut adalah dengan memberikan atau menerapkan sanksi pidana bagi pelaku kejahatan.

Penjatuhan sanksi pidana terhadap seseorang yang telah melakukan perbuatan pidana merupakan bagian yang sangat penting dalam mewujudkan sistem peradilan pidana (criminal justice system), dimana dalam hal ini hakim seharusnya sudah mampu memilih jenis sanksi pidana yang tepat yang akan dijatuhkan kepada pelaku. Oleh karenanya peran hakim sangat menentukan efektifitas pemidanaan yang akan dijatuhkannya terhadap seorang pelaku. ${ }^{24}$

Berdasarkan ketentuan dalam Pasal 10 Kitab Undang-Undang Hukum Pidana, hukuman dibedakan menjadi 2 bentuk, yaitu hukuman pokok dan hukuman tambahan. Hukuman pokok dibedakan menjadi hukuman mati, hukuman penjara, hukuman kurungan, hukuman denda dan hukuman tutupan. Sedangkan pencabutan beberapa hak tertentu, perampasan barang tertentu dan pengumuman keputusan hakim adalah merupakan hukuman tambahan.

${ }^{24}$ Gatot Sugiharto, "Relevansi Kebijakan Penetapan Pidana Kerja Sosial Dalam Sistem Pemidanaan Di Indonesia”, Jurnal Ilmu Hukum Novelty, Vol. 7 No. 1, Februari 2016, hlm. 84. 
Hukuman penjara merupakan bentuk pemidanaan dengan menahan kebebasan seseorang yang telah melakukan suatu tindak pidana sebagaimana yang dijelaskan dalam Pasal 22 Kitab Undang-Undang Hukum Pidana (KUHP). Terhadap pelaku kejahatan di Indonesia banyak yang dikenakan sanksi pidana, akan tetapi walaupun telah dikenakan sanksi pidana bahwa angka kejahatan di Indonesia terus meningkat dari tahun ke tahun, baik peningkatan secara kualitas maupun peningkatan secara kuantitas. Meningkatnya kejahatan dipicu oleh berbagai persoalan, seperti persoalan ekonomi, sosial, konflik dan rendahnya kesadaran hukum, bahkan disebabkan oleh hal-hal yang yang sifatnya sederhana. Pidana perampasan kemerdekaan baik penjara maupun kurungan menjadi sangat primadona dalam penjatuhan sanksi pidananya, terlebih dikaitkan dengan tujuan adanya efek jera bagi para pelaku kejahatan dan tercapainya upaya pencegahannya. Terkait perkembangan konsep baru dalam hukum pidana yang menonjol saat ini adalah perkembangan mengenai sanksi alternatif, dari pidana hilangnya kemerdekaan seseorang menjadi pidana denda, terutama terhadap tindak pidana yang diancam dengan pidana penjara di bawah satu tahun. Munculnya alternatif pidana penjara adalah merupakan wujud dari kritik terhadap efek buruk pidana penjara. ${ }^{25}$ Dari aspek kebijakan kriminal, penetapan sanksi hukum pidana seharusnya dilakukan melalui pendekatan rasional. Melalui pendekatan rasional, maka tujuan akhir dari penetapan sanksi pidana tidak terlepas dari penetapan tujuan yang ingin dicapai oleh kebijakan kriminal secara keseluruhan, yakni perlindungan masyarakat untuk mencapai kesejahteraan. Dari sisi hukum positif, konsep tujuan pemidanaan belum ada atau tidak ditemukan, akan tetapi wacana tujuan pemidanaan telah dirumuskan di dalam konsep RUU KUHP. Di dalam konsep RUU KUHP ditemukan ketentuan mengenai pemidanaan yang mengatur tentang bagaimana pengadilan akan menentukan atau menjatuhkan pidana kepada pelaku yang didasarkan pada pertimbangan berbagai faktor untuk mencapai pemidanaan yang dianggap patut (proper). ${ }^{26}$

${ }^{25}$ Rugun Romaida Hutabarat, "Problematik Lembaga Pemasyarakatan Dalam Sistem Peradilan Terpadu", Jurnal Muara Ilmu Sosial, Humaniora dan Seni, Vol. 1 No. 1, April 2017, hlm. 42.

26 Marcus Priyo Gunarto, "Sikap Memidana Yang Berorientasi Pada Tujuan Pemidanaan", Mimbar Hukum, Vol. 21, No. 1, Februari 2009, hlm. 103. 
Keterkaitan antara pidana kerja sosial dengan kebijakan kriminal dapat dipahami sebagai alternatif bentuk sanksi pidana berupa sanksi pidana kerja sosial yang dapat dioptimalkan dalam menanggulangi kejahatan. ${ }^{27}$ Penggunaan teori yang tepat dalam mewujudkan tujuan pemidanaan tidak terbatas hanya untuk mengayomi masyarakat dari perbuatan jahat oleh terpidana, tetapi turut juga mengayomi orang yang tersesat yang telah melakukan kejahatan dengan cara memberikan bekal hidup kepada pelaku kejahatan sebagai warga negara yang berguna dalam masyarakat. Dari pengayoman tersebut jelaslah bahwa penjatuhan pidana bukanlah tindakan pembalasan dari negara. ${ }^{28}$

Berdasarkan peraturan perundang-undangan bahwa tahapan dalam proses peradilan pidana di Indonesia ada 4 yakni, tahap penyelidikan dan penyidikan, tahap penuntutan, tahap pemeriksaan pengadilan dan tahap pelaksanakan putusan. ${ }^{29}$ Di dalam prakteknya, seseorang dengan sangat mudah dijadikan tersangka yang hanya didasarkan pada adanya 2 alat bukti saja. Namun demikian, penyidik sebagai ujung tombak yang menentukan apakah perkara ini merupakan perkara pidana atau perkara perdata menjadi tidak berjalan dengan baik karena hanya selalu berpatokan kepada adanya 2 alat bukti saja, padahal jika perkara tersebut merupakan perkara pidana, seharusnya tidak semua perkara pidana harus masuk ke ranah pengadilan mengingat bahwa hukum pidana merupakan upaya terakhir atau ultimum remedium. Upaya penyelesaian restorative justice yang menjadi kewenangan penyidik seharusnya dapat terlaksana dengan baik dan optimal apabila hal tersebut memang dimungkinkan dan adanya kehendak dari penyidik. Penerapan asas ultimum remedium menuntut penegakan hukum lebih bijaksana dalam menerapkan pidana, dimana pidana merupakan upaya terakhir selain upaya penegakan hukum administratif dan upaya hukum perdata, karena adanya keterbatasan hukum pidana dalam menjangkau sebabsebab kejahatan yang sedemikian kompleks dalam menanggulangi kejahatan. Hukum pidana merupakan pengobatan yang simptomatik yang mengandung

\footnotetext{
${ }^{27}$ Ganda Nugraha, Eryana. Kebijakan Legislatif Tentang Pidana Kerja Sosial Di Indonesia. Diss. Program Pasca Sarjana Universitas Diponegoro, 2003, hlm. 96

28 Ismail Rumadan, "Problem Lembaga Pemasyarakatan Di Indonesia Dan Reorientasi Tujuan Pemidaaan”, Jurnal Hukum dan Peradilan, Vol. 2 No. 2, Juli 2013, hlm. 270.

${ }^{29}$ Rusli Muhammad, Sistem Peradilan Pidana di Indonesia, Cetakan Pertama, UII Press, Yogyakarta, 2012, hlm. 62 .
} 
sifat kontradiktif dan mengandung efek samping yang negatif, serta berfungsinya hukum pidana memerlukan sarana pendukung yang lebih bervariasi dan lebih menuntut "biaya tinggi". 30

Selain itu, dampak kelebihan kapasitas pada lembaga pemasyarakatan adalah sebagai faktor kriminogenik terhadap pengulangan tindak pidana, yakni memungkinkan terjadinya beberapa tindakan yang dapat memicu terjadinya pelanggaran maupun tindak pidana itu sendiri. Hal ini perlu mendapatkan perhatian serius mengenai perlu adanya alternatif pemidanaan dan penulis berpendapat bahwa pidana sosial dan ganti rugi dapat dijadikan sebagai alternatif pengganti pidana penjara agar tujuan pemidanaan yang sesungguhnya dapat tercapai. Gambaran terhadap kelebihan over kapasitas dapat terlihat pada gambar di bawah ini.

Tabel 1.

Jumlah Penghuni Perkanwil dari Sistem Data Pemasyarakatan ${ }^{31}$

\begin{tabular}{|c|c|c|c|c|c|c|}
\hline No & Satker & Tahanan & Napi & $\begin{array}{c}\text { Total } \\
\text { Tahanan \& } \\
\text { Napi }\end{array}$ & Kapasitas & $\begin{array}{c}\text { \% Over } \\
\text { Kapasitas }\end{array}$ \\
\hline 1 & Kanwil Aceh & 1733 & 5970 & 7703 & 4050 & 90 \\
\hline 2 & Kanwil Bali & 393 & 2476 & 2869 & 1518 & 89 \\
\hline 3 & $\begin{array}{l}\text { Kanwil Bangka } \\
\text { Belitung }\end{array}$ & 325 & 1726 & 2051 & 1368 & 50 \\
\hline 4 & Kanwil Banten & 1797 & 8022 & 9819 & 5197 & 89 \\
\hline 5 & Kanwil Bengkulu & 439 & 1865 & 2304 & 1632 & 41 \\
\hline 6 & Kanwil D.I.Y & 337 & 887 & 1224 & 2010 & 0 \\
\hline 7 & Kanwil Dki Jakarta & 4516 & 10623 & 15139 & 5791 & 161 \\
\hline 8 & Kanwil Gorontalo & 189 & 687 & 876 & 888 & 0 \\
\hline 9 & Kanwil Jambi & 740 & 3180 & 3920 & 2256 & 74 \\
\hline 10 & Kanwil Jawa Barat & 3313 & 16716 & 20029 & 15576 & 29 \\
\hline 11 & $\begin{array}{l}\text { Kanwil Jawa } \\
\text { Tengah }\end{array}$ & 2286 & 9287 & 11573 & 9258 & 25 \\
\hline 12 & Kanwil Jawa Timur & 6504 & 18536 & 25040 & 12846 & 95 \\
\hline 13 & $\begin{array}{l}\text { Kanwil Kalimantan } \\
\text { Barat }\end{array}$ & 1008 & 3704 & 4712 & 2529 & 86 \\
\hline 14 & $\begin{array}{l}\text { Kanwil Kalimantan } \\
\text { Selatan }\end{array}$ & 1688 & 7344 & 9032 & 3467 & 161 \\
\hline 15 & $\begin{array}{l}\text { Kanwil Kalimantan } \\
\text { Tengah }\end{array}$ & 618 & 3345 & 3963 & 2344 & 69 \\
\hline
\end{tabular}

30 Eman Sulaeman, "Batas-Batas Kemampuan Hukum Dalam Menghadapi Perubahan Sosial”, Jurnal Hukum Islam (JHI), Vol. 12 No. 1, Juni 2014, hlm. 23

${ }^{31}$ http://smslap.ditjenpas.go.id/ 


\begin{tabular}{|c|c|c|c|c|c|c|}
\hline 16 & $\begin{array}{l}\text { Kanwil Kalimantan } \\
\text { Timur }\end{array}$ & 1681 & 9697 & 11378 & 3586 & 217 \\
\hline 17 & $\begin{array}{l}\text { Kanwil Kepulauan } \\
\text { Riau }\end{array}$ & 549 & 3689 & 4238 & 2733 & 55 \\
\hline 18 & Kanwil Lampung & 1378 & 6194 & 7572 & 5348 & 42 \\
\hline 19 & Kanwil Maluku & 376 & 926 & 1302 & 1459 & 0 \\
\hline 20 & $\begin{array}{l}\text { Kanwil Maluku } \\
\text { Utara }\end{array}$ & 202 & 845 & 1047 & 1477 & 0 \\
\hline 21 & $\begin{array}{l}\text { Kanwil Nusa } \\
\text { Tenggara Barat }\end{array}$ & 962 & 1785 & 2747 & 1269 & 116 \\
\hline 22 & $\begin{array}{l}\text { Kanwil Nusa } \\
\text { Tenggara Timur }\end{array}$ & 531 & 2179 & 2710 & 2903 & 0 \\
\hline 23 & Kanwil Papua & 406 & 1657 & 2063 & 2267 & 0 \\
\hline 24 & Kanwil Papua Barat & 218 & 700 & 918 & 1004 & 0 \\
\hline 25 & Kanwil Riau & 2434 & 9283 & 11717 & 4455 & 163 \\
\hline 26 & $\begin{array}{l}\text { Kanwil Sulawesi } \\
\text { Barat }\end{array}$ & 202 & 595 & 797 & 1022 & 0 \\
\hline 27 & $\begin{array}{l}\text { Kanwil Sulawesi } \\
\text { Selatan }\end{array}$ & 2301 & 6757 & 9058 & 5843 & 55 \\
\hline 28 & $\begin{array}{l}\text { Kanwil Sulawesi } \\
\text { Tengah }\end{array}$ & 669 & 2191 & 2860 & 1711 & 67 \\
\hline 29 & $\begin{array}{l}\text { Kanwil Sulawesi } \\
\text { Tenggara }\end{array}$ & 535 & 1608 & 2143 & 2146 & 0 \\
\hline 30 & $\begin{array}{l}\text { Kanwil Sulawesi } \\
\text { Utara }\end{array}$ & 490 & 1659 & 2149 & 2145 & 0 \\
\hline 31 & $\begin{array}{l}\text { Kanwil Sumatera } \\
\text { Barat }\end{array}$ & 1155 & 4122 & 5277 & 3217 & 64 \\
\hline 32 & $\begin{array}{l}\text { Kanwil Sumatera } \\
\text { Selatan }\end{array}$ & 2303 & 10828 & 13131 & 6605 & 99 \\
\hline 33 & $\begin{array}{l}\text { Kanwil Sumatera } \\
\text { Utara }\end{array}$ & 7307 & 21770 & 29077 & 12574 & 131 \\
\hline
\end{tabular}

Berdasarkan tabel tersebut di atas, dapat kita lihat bahwa terjadi over kapasitas di beberapa wilayah dan hal tersebut akan menjadi suatu hal yang kontradiktif apabila dihubungkan dengan adanya suatu pernyataan keberhasilan Lapas dalam melakukan pembinaan. Oleh karena itu, evaluasi terkait efektifitas pidana penjara dalam rangka memberikan perlindungan bagi masyarakat dan perlindungan individu sangat diperlukan. Hakikat tujuan pemidanaan dalam konteks Pancasila yakni pendekatan multi dimensional yang bersifat mendasar terhadap dampak tindak pidana, dengan demikian tujuan pemidaaan adalah untuk memperbaiki kerusakan baik yang bersifat individual, maupun yang 
bersifat sosial yang diakibatkan dari suatu tindak pidana. Oleh karenanya, tujuan pemidanaan harus diarahkan untuk memelihara dan mempertahankan kesatuan masyarakat. ${ }^{32}$ Cesare Beccaria dalam bukunya perihal kejahatan dan hukuman menyebutkan bahwa hukuman harus bersifat sosial, langsung dan seperlunya, sekecil mungkin dalam kasus yang diberikan, disesuaikan dengan kejahatan dan ditentukan oleh hukum. ${ }^{33}$

Bahwa para penegak hukum harus betul-betul memahami tujuan pemidanaan baik dari segi perlindungan masyarakat maupun dari aspek pembinaan bagi pelaku tindak pidana. Demikian juga halnya penegak hukum dari penyidik agar tidak selalu memaksakan dan menetapkan seseorang yang diduga melakukan tindak pidana menjadi tersangka dan memproses lebih jauh ketingkat penuntutan sampai pada putusan hakim dengan menggunakan kewenangannya untuk mencari solusi atau alternatif lainnya yang dipandang dapat memberikan yang terbaik bagi semua pihak baik melalui upaya musyawarah (restoratif justice) maupun dengan menerapkan sanksi membayar biaya ganti rugi dan/atau kerja sosial yang sesuai dengan karakter dan keahliannya. Dengan demikian pelaku tindak pidana sesuai dengan karakter dan keahliannya tidak perlu lagi menjalani putusan di lembaga pemasyarakatan dan sekaligus dapat menjawab tantangan agar tidak terjadinya over kapasitas di lembaga pemasyarakatan, juga dapat menghemat anggaran negara serta tetap memberikan kesempatan kepada tersangka untuk tetap produktif.

Dilihat dari tingkat efektifitasnya dan dalam upaya mengembalikan nilainilai tujuan pemidanaan, maka penjara bukanlah tujuan utama bagi orang yang telah melakukan kejahatan. Oleh karenanya perlu jalur hukum atau suatu pemikiran lain untuk meminimalisir penerapan pidana penjara baik melalui musyawarah (restoratif justice) maupun melalui bentuk kerja sosial atau ganti rugi. Untuk menunjang proses pelaksanaan sanksi kerja sosial dan ganti rugi dapat terimplementasi dengan baik perlu didukung dengan sistem yang baik juga, artinya tidak boleh ada aturan yang kontradiktif terhadap pelaksanaan sanksi

${ }^{32}$ Eko Soponyono, "Kebijakan Perumusan Sistem Pemidanaan Yang Berorientasi Pada Korban”, $M M H$, Jilid 41 No. 1, Januari 2012, hlm. 30

${ }_{33}$ Cesare Beccaria., Perihal Kejahatan dan Hukuman, Cetakan Pertama, Genta Publishing, Yogyakarta, 2011, hlm. 153. 
tersebut baik secara teknis maupun non teknis, misalnya pelaksanaan sanksi sosial dimana narapidana dipekerjakan di perusahaan tertentu akan tetapi terkendala dengan jarak tempuh sehingga mengakibatkan pelaksanaan kerja sosial tersebut tidak berjalan efektif.

Pidana kerja sosial dan ganti rugi memiliki beberapa kelebihan jika dibandingkan dengan pidana penjara, yaitu terpidana dapat menjalankan kehidupannya secara normal sehingga tetap dapat menjalankan kewajibannya bagi keluarga dan masyarakat, meniadakan efek negatif berupa stigma atau labeling yang tumbuh di masyarakat, dari segi ekonomi pidana kerja sosial dan ganti rugi lebih murah, bahkan dapat menjadi salah satu sumber pemasukan bagi Negara. Kerugian negara secara pasti dengan menerapkan pidana penjara, sebagai berikut.

\section{Asumsi Kebutuhan Biaya Makan Tahanan dan Narapidana untuk 1 hari}

- Jika asumsi biaya untuk makan per orang adalah Rp. 7500,- per satu kali makan, sehingga biaya tiga kali makan adalah : Rp. 7500 × 3 = Rp. 22.500,-

- Jumlah tahanan dan narapidana seperti yang telah disebutkan diatas adalah sebanyak 269.425 orang.

- Jika diasumsikan biaya makan tahanan dan narapidana perhari maka anggaran yang dibutuhkan adalah sebesar : Rp. 22.500,- x $269.425=\mathrm{Rp}$. 6.062.062.500,-

Secara filosofi, pidana kerja sosial ini sangat sesuai dengan Pancasila sila kedua dan sila kelima, yakni adanya nilai-nilai pengakuan terhadap martabat manusia dengan berlaku adil dan menghormati hak asasi manusia melalui ditempatkannya narapidana di tempat kerja sesuai dengan keterampilan dan bakat narapidana serta dilakukannya pembinaan terhadap narapidana oleh petugas yang ahli adalah sesuai dengan sila kelima Pancasila yakni nilai kerja keras sebagai sarana untuk mencapai keadilan sosial.

Menyadari adanya sisi positif dari penerapan pidana kerja sosial dan ganti rugi sebagaimana tersebut di atas akan memberikan pemahaman, bahwa pidana kerja sosial dan ganti rugi adalah sebagai upaya untuk menyadarkan masyarakat akan bahayanya suatu tindakan kejahatan beserta resiko yang akan ditimbulkan dan konsekuensinya. Dengan demikian dapat disimpulkan, bahwa pidana kerja sosial dan ganti rugi dapat memenuhi aspek tujuan pemidanaan yang sesungguhnya yang 
dapat memberikan perlindungan bagi masyarakat. Oleh karenanya, dilihat dari aspek perlindungan masyarakat bahwa pidana kerja sosial dan ganti rugi sangat relevan dengan tujuan pemidanaan dan merupakan bentuk pertanggungjawaban pidana yang syarat dengan muatan perlindungan hak asasi manusia. Sebagai salah satu contoh yang ada dalam Perkara Nomor : 253/Pid.B/2013/PN.Jr., hakim berani menjatuhkan sanksi pidana kerja sosial terhadap pelaku kejahatan Cyber Crime dan alternatif dari sanksi pidana penjara yang diganti dengan pidana kerja sosial dirasakan tepat, dimana hakim melihat karakter dari pelaku yang mempunyai keunikan tersendiri, karena pelaku cyber crime pada dasarnya seseorang yang mempunyai kemampuan lebih untuk mengoperasikan komputer serta memahami bagian-bagian software yang berkaitan dengan website maupun bagian-bagian yang berkaitan dengan penyimpanan data. Apabila kemampuan dari seorang pelaku Cyber Crime dapat diberdayakan di instansi-instansi pemerintah maupun ditengahtengah masyarakat dengan cara diberi kepercayaan untuk memberikan pelatihan ataupun penyuluhan, maka akan memberikan dampak yang positif dan sangat baik dalam mendukung perkembangan teknologi. Selain itu dengan kemampuan yang dimilikinya tersebut, tidak menutup kemungkinan bagi terpidana dapat dipekerjakan di intansi terkait apabila telah selesai menjalani pidana kerja sosial. Penerapan pidana kerja sosial dan ganti rugi dapat dilaksanakan dengan mengklasifikasikan beberapa tindak pidana sehingga cara yang akan di tempuh dalam memberikan pidana kerja sosial dan ganti rugi juga akan berbeda sesuai dengan karakteristik pelaku dan bentuk kejahatannya. Pidana kerja sosial dan ganti rugi menurut penulis lebih mengedepankan perlindungan hak asasi manusia pada diri pelaku, di mana dalam pidana kerja sosial dan ganti rugi bagi terpidana harkat dan martabatnya pun akan tetap terjaga sebagai manusia yang tetap berhak mendapatkan hak pendidikan, hak pekerjaan yang layak dan sebagainya.

Berdasarkan hal tersebut, penerapan sanksi pidana tidak dapat dilepaskan dengan tujuan pemidanaan sebagai bagian integral dari kebijakan kriminal, dimana tujuan pemidanaan juga harus dilakukan melalui pendekatan humanistis yakni memperhatikan hak asasi manusia, pendekatan ekonomis yakni mempertimbangkan antara biaya yang dikeluarkan dengan hasil yang ingin dicapai serta memperhatikan efektifitasnya, pendekatan komprehensif yakni (a) 
menentukan dan memastikan jenis sanksi tersebut ditiadakan, (b) menilai penerapan sanksi yang dijatuhkan, (c) mengevaluasi dampak penggunaan penerapan sanksi tersebut, (d) re-evaluasi terhadap sanksi yang diberlakukan. ${ }^{34}$

Dalam perspektif hukum pidana di Indonesia, pidana kerja sosial tidak boleh dimasukkan ke dalam aspek komersial, karenanya pelaksanaan pidana kerja sosial adalah murni dalam rangka mewujudkan teori keadilan restoratif, sehingga pada akhirnya pidana kerja sosial lebih bersifat membina daripada bersifat menghukum sebagaimana arah tujuan restoratif justice. ${ }^{35}$ Pidana kerja sosial mempunyai nilai luhur, yaitu melakukan perbuatan yang bernilai sosial karena dilakukan di organisasi kemasyarakatan yang tidak mengutamakan perolehan keuntungan. Hal ini sesuai dengan sila ke dua dan ke lima yang mengandung nilai kemanusiaan dan keadilan. ${ }^{36}$

Penjatuhan pidana kerja sosial juga bertujuan untuk membangun emosional terpidana sehingga dapat mengurangi rasa bersalah serta dapat diterima kembali oleh masyarakat. Dengan memberikan kesempatan kepada terpidana secara aktif melakukan pekerjaan yang bermanfaat bagi masyarakat, hal ini merefleksikan beberapa prinsip tatanan yang harus terkandung dalam pembaharuan hukum pidana dengan mempertimbangkan efek sosio psikologis dari pihak terpidana dan masyarakat luas. Penjatuhan pidana kerja sosial lebih bertitik berat pada pengembalian nama baik dari terpidana dan secara tidak langsung diharapkan dapat memberikan suatu pembelajaran kepada terpidana untuk memperbaiki kesalahan yang diperbuat dan memberikan suatu inisiatif bagi terpidana untuk dapat melakukan suatu pekerjaan yang bermanfaat bagi masyarakat, sehingga tujuan pemidanaan dapat tercapai.

Dalam melaksanakan pidana kerja sosial sebagai alternatif dari sistem pemidanaan tersebut, selain dukungan secara sistematis dan budaya hukum maka diperlukan juga substansi hukum yang mengatur baik secara praktis maupun secara teknis dalam bentuk peraturan, baik itu dalam bentuk PERMA,

\footnotetext{
34 Yolanda, L. (2016). Loc. Cit. Hlm. 13.

35 Jamin Ginting, "Sanksi Kerja Sosial Sebagai Alternatif Bentuk Pemidanaan Dalam Sistem Hukum Di Indonesia”, Law Review, Vol. XIX No. 3, Maret 2020, hlm. 261.

36 Widodo, Perspektif Hukum Pidana Dan Kebijakan Pemidanaan Diversi dan Keadilan Restoratif, Terorisme, Cybercrime, Pidana Mati dan Peradilan Sesat, Cetakan Pertama, Aswaja Pressindo, Yogyakarta, 2017, hlm. 152.
} 
Peraturan Kepolisian maupun PP yang dapat dijadikan sebagai landasan hukum bagi penegak hukum sampai dengan diundangkannya KUHP yang baru. Hal tersebut dipandang penting dan mendesak sehingga para penegak hukum dapat menjalankan tugas dan wewenangnya dengan baik, khususnya bagi hakim sebagai corong keadilan dapat mendukung tercapainya tujuan pemidanaan yang berkeadilan. Oleh karena itu, agar tujuan pemidanaan dapat tercapai sesuai dengan maksud dan tujuannya dan demi terwujudnya ketertiban, keadilan serta kesejahteraan masyarakat, maka perlu adanya dukungan dan kontribusi dari semua pihak baik pemerintah, para penegak hukum, dan masyarakat.

\section{Penutup}

Bahwa sanksi pidana kerja sosial dan ganti rugi sebagai alternatif dari pemidanaan, dimana sanksi pidana kerja sosial lebih menitikberatkan pada pengembalian nama baik dari terpidana dan diharapkan dapat memberikan suatu pembelajaran kepada terpidana untuk memperbaiki kesalahannya serta memberikan suatu inisiatif bagi terpidana untuk dapat melakukan suatu pekerjaan yang bermanfaat bagi masyarakat dan bagi dirinya. Akan tetapi penerapan sanksi pidana kerja sosial dan ganti rugi belum dapat diterapkan secara optimal oleh para penegak hukum karena belum adanya regulasi yang mengatur. Oleh karena itu, demi terwujudnya tujuan pemidanaan yang sesungguhnya dan yang berkeadilan, maka pemerintah beserta lembaga-lembaga terkait harus segera menerbitkan regulasinya yang dapat dijadikan sebagai landasan hukum bagi para penegak hukum dalam menjalankan tugasnya serta adanya keberanian dari penegak hukum untuk menerapkan pidana kerja sosial.

\section{Daftar Pustaka}

\section{Buku}

Anwar, Yesmil. "Adang, Sistem Peradilan Pidana: Konsep, Komponen, dan Pelaksanaannya dalam Penegakan Hukum di Indonesia." 2009.

Beccaria, Cesare, Perihal Kejahatan dan Hukuman, Cetakan Pertama, Genta Publishing, Yogyakarta, 2011.

Muhammad, Rusli, Sistem Peradilan Pidana di Indonesia, Cetakan Pertama, UII Press, Yogyakarta, 2012. 
Samosir, C. Djisman, Penologi dan Pemasyarakatan, Cetakan Pertama, Nuansa Aulia, Bandung, 2016.

Setiadi, Edi, Sistem peradilan Pidana Terpadu dan Sistem Penegakan Hukum di Indonesia, Cetakan Pertama, Prenada Media Group, Jakarta, 2017.

Widodo, Perspektif Hukum Pidana Dan Kebijakan Pemidanaan Diversi dan Keadilan Restoratif, Terorisme, Cybercrime, Pidana Mati dan Peradilan Sesat, Cetakan Pertama, Aswaja Pressindo, Yogyakarta, 2017.

\section{Jurnal}

Akhmaddhian Suwari, "Peran Pemerintah Daerah Dalam Mewujudkan Hutan Konservasi Berdasarkan Undang-Undang Nomor 41 Tahun 1999 Tentang Kehutanan", Jurnal Dinamika Hukum, Vol. 13 No. 3, September 2013.

Akmal Fachrurrozy, "Penologi Pengayoman, Sebuah Tinjauan Pemidanaan Dalam Integrasi Ilmu Pengetahuan", Jurnal Khatulistiwa Law Review, Vol. 1 No. 1, April 2020.

Ali Mahrus, "Sistem Peradilan Pidana Progresif; Alternatif Dalam Penegakan Hukum Pidana", Jurnal Hukum, Vol. 2 No. 14, April 2017.

Almendo Meldy Ance, "Prinsip Keadilan Dalam Tanggungjawab Negara Terhadap Korban Tindak Pidana Karena Pelaku Tidak Menjalani Pemidanaan", Jurnal Yuridika, Vol. 31 No. 1, Januari 2016.

Angkasa, "Over Capacity Narapidana Di Lembaga Pemasyarakatan, Faktor Penyebab, Implikasi Negatif, Serta Solusi Dalam Upaya Optimalisasi Pembinaan Narapidana", Jurnal Dinamika Hukum, Vol. 10 No. 3 September 2010.

Atmasasmita Romli, "Memahami Teori Hukum Integratif”, Jurnal Legalita, Vol. III No. 2, Desember 2012.

Eko Soponyono, "Kebijakan Perumusan Sistem Pemidanaan Yang Berorientasi Pada Korban", MMH, Jilid 41 No. 1, Januari 2012.

Ginting Jamin, "Sanksi Kerja Sosial Sebagai Alternatif Bentuk Pemidanaan Dalam Sistem Hukum Di Indonesia", Law Review, Vol. XIX No. 3, Maret 2020.

Gunarto Marcus Priyo, "Sikap Memidana Yang Berorientasi Pada Tujuan Pemidanaan", Mimbar Hukum, Vol. 21, No. 1, Februari 2009.

Haji Son, Gunarto, Widayati, "Implementasi Kewenangan Diskresi Kepolisian Dalam Penanganan Tindak Pidana Di Polres Demak Jawa Tengah", Jurnal Hukum Khaira Ummah, Vol. 13 No. 1, Maret 2018.

Harkrisnowo Harkristuti, "Redefinisi Pidana dan Pemidanaan Korporasi Dalam Perspektif Rancangan Undang-Undang Kitab Undang-Undang Hukum Pidana", Jurnal Legislasi Indonesia, Vol. 16 No. 4 Desember 2019. 
Hutabarat Rugun Romaida, "Problematik Lembaga Pemasyarakatan Dalam Sistem Peradilan Terpadu", Jurnal Muara Ilmu Sosial, Humaniora dan Seni, Vol. 1 No. 1, April 2017.

Maryani Desy, "Faktor-Faktor Penyebab Tidak Tercapainya Tujuan Pemidanaan Lembaga Pemasyarakatan Di Indonesia", Jurnal Hukum Schasen, Vol. 1 No. 1 April 2015.

Mubarok Nafi, "Pidana Qisas dalam Perspektif Penologi", Jurnal Al-Qanun, Vol. 20 No. 2 Desember 2017.

Mukhidin, "Hukum Progresif Sebagai Solusi Hukum Yang Mensejahterakan Rakyat", Jurnal Pembaharuan Hukum, Vol. 1 No. 3 September 2014.

Nugroho Bastianto, "Peranan Alat Bukti Dalam Perkara Pidana Dalam Putusan Hakim Menurut KUHAP", Jurnal Yuridika, Vol. 32 No. 1, Januari 2017.

Priyantoko Guntur, "Penerapan Diskresi Kepolisian Dalam Penanganan Unjuk Rasa", De Lega Lata, Vol. 1 No. 1, Januari 2016.

Rumadan Ismail, "Problem Lembaga Pemasyarakatan Di Indonesia Dan Reorientasi Tujuan Pemidaaan", Jurnal Hukum dan Peradilan, Vol. 2 No. 2, Juli 2013.

Situmeang, Sahat. 2019. “KEBIJAKAN KRIMINAL DALAM PENEGAKAN HUKUM UNTUK MEWUJUDKAN KEADILAN DALAM PERSPEKTIF HAK ASASI MANUSIA". Res Nullius Law Journal 1 (1). https://doi.org/10.34010/rnlj.v1i1.2492.

Sugiharto Gatot, "Relevansi Kebijakan Penetapan Pidana Kerja Sosial Dalam Sistem Pemidanaan Di Indonesia", Jurnal Ilmu Hukum Novelty, Vol. 7 No. 1, Februari 2016.

Sulaeman Eman, "Batas-Batas Kemampuan Hukum Dalam Menghadapi Perubahan Sosial", Jurnal Hukum Islam (JHI), Vol. 12 No. 1, Juni 2014.

Sulhin Iqrak, "Filsafat (Sistem) Pemasyarakatan", Jurnal Kriminologi Indonesia, Vol. 7 No. 1 Mei 2010.

Yani Mas Ahmad, "Pengendalian Sosial Kejahatan : Suatu Tinjauan Terhadap Masalah Penghukuman Dalam Perspektif Sosiologi", Jurnal Cita Hukum, Vol. 3 No. 1 Juni 2015.

\section{Hasil Penelitian / Tugas Akhir}

Ganda Nugraha, Eryana. Kebijakan Legislatif Tentang Pidana Kerja Sosial Di Indonesia. Diss. Program Pasca Sarjana Universitas Diponegoro, 2003.

Yolanda, Lise. Eksistensi Pidana Kerja Sosial Sebagai Sanksi Pidana Dalam Rancangan Undang-Undang Kuhp Indonesia. Diss. Universitas Islam Indonesia, 2016.

\section{Internet}

Atmasasmita Romli, Teori Hukum Integratif Rekonstruksi Terhadap Teori Hukum, http://news.unair.ac.id/2019/06/12/teori-hukum-integratif-sebagai- 
Sahat MTS., Musa DP., dan Wahyudi. Optimalisasi Peran Penegak Hukum... 525

kontribusi-pemikiran-evolusioner-di-indonesia/, Diakses pada tanggal 25 Juni 2020.

\section{Peraturan Perundang-Undangan}

Undang-Undang No. 8 Tahun 1981 tentang Kitab Undang-Undang Hukum Pidana

Undang-Undang No. 12 Tahun 1995 tentang Pemasyarakatan

Undang - Undang Nomor 2 Tahun 2002 Tentang Kepolisian Negara Republik Indonesia 